\title{
The Effect of Democratic Autocratic and Laissez-Faire (Free) Leadership Style of Kindergarten Headmaster toward Teacher Discipline Performance at Kindergartens in Southeast Pontianak District
}

\author{
F.Puji Astuti ${ }^{1)}$, Aunurrahman ${ }^{2)}$, Wahyudi $^{3)}$ \\ ${ }^{1)}$ Universitas Tanjungpura, Pontianak, Indonesia \\ E-mail: pujiastuti261077@gmail.com \\ ${ }^{2)}$ Universitas Tanjungpura, Pontianak, Indonesia \\ E-mail: aunuruntan@gmail.com \\ ${ }^{3)}$ Universitas Tanjungpura, Pontianak, Indonesia \\ E-mail: wyudi_fkip@yahoo.com
}

\begin{abstract}
A formal education institution achieving success one of the factors is the leadership style of the Headmaster. One that wants to be improved through leadership style is work discipline for teachers. This study has several objectives, namely (1) To determine the influence of democratic leadership style on the work discipline of kindergarten teachers in Southeast Pontianak Subdistrict; (2) To find out the influence of autocratic leadership style on the work discipline of Kindergarten teachers in Southeast Pontianak District; (3) To determine the effect of laissez-faire (free) leadership style on the work discipline of kindergarten teachers in Southeast Pontianak Sub-district; (4) Describe the simultaneous influence of leadership styles (democratic, autocratic, and laissez-faire (free)) TK headmasters on the work discipline of kindergarten teachers in Southeast Pontianak Sub-district. The research approach used in this study is a quantitative approach. The data source referred to in this study is the Headmaster of Kindergarten and Kindergarten teachers in the Southeast Pontianak Subdistrict of Pontianak City which amounts to a total of 83 people from 7 public and private kindergartens. In this study using a non-random sample is a purposive sampling method with a total sample of 34 teachers. The results showed that (1) the leadership style of the kindergarten headmasters in Southeast Pontianak sub-district varied, which can be seen from the results of the percentage of democratic leadership style of $39.8 \%$, autocratic leadership style of $26.5 \%$, and laizes-faire leadership style of 33,7\%; (2) The discipline of the performance of kindergarten teachers in the Southeast Pontianak sub-district has been good, which can be seen from the results of the percentage of discipline of teacher performance of $85.01 \%$ in the high / good category; (3) There is a significant influence between the leadership style of the Kindergarten Headmaster and the discipline of performance of Kindergarten teachers in the Southeast Pontianak District; (4) There is a significant influence between the democratic leadership style of the Headmaster of Kindergarten on the discipline of performance of Kindergarten teachers in Southeast Pontianak Sub-district; (5) There is a nonsignificant influence between the autocratic leadership style of the Headmaster of Kindergarten on the discipline of the performance of Kindergarten teachers in Southeast Pontianak District; (6) There is a nonsignificant influence between the autocratic leadership style of the headmaster of kindergarten on the discipline of performance of kindergarten teachers in the Southeast Pontianak sub-district.
\end{abstract}

Keywords: Leadership Style; Work Discipline

\section{INTRODUCTION}

Education is an effort to gain knowledge, insight, skills, and certain expertise in individuals to develop themselves as a human level to be able to deal with any changes that occur throughout their lives. In the change, there are also many determinants that influence the continuity of a country's development, namely the quality and quantity of adequate human 
resources from various aspects to achieve national development goals.

The development of the world of education from year to year has always experienced changes that are in line with the challenges and obstacles in preparing quality human resources (HR) that are able to compete in the era of globalization. One of the problems faced by our nation is the low quality of education at every level. If the quality of education is not guaranteed, the establishment of the State and nation is not yet healthy and is still doubtful to compete in the academy world.

The school principal is an education leader at the education unit level, who must be responsible for the progress and withdrawal of the school he leads. Not infrequently the principal receives a threat; if he cannot advance his school, he will be transferred or dismissed from his position. Therefore, principals are required to have various abilities, both related to management issues and leadership, so that they can develop and advance their schools effectively, efficiently, independently, productively, and accountably. These conditions require tasks that must be carried out by educational staff in accordance with their respective roles and functions, ranging from the macro level to the micro level, namely school-level education.

In schools that play an important role in determining the quality of education, namely principals and teachers. The school principal is a central figure who must be a girl and for all school residents. Therefore, to realize the vision and mission of school, and achieve the expected goals, it is necessary to prepare the school principal who is able to understand the role of school management and the task as a leader.

To carry out the managerial tasks above, and also respond to the changing demands at this time, principals must have strong leadership to be able to implement the various programs they foster effectively. It is because the headmaster of the school is not only responsible for managing teachers, and staff of students, but also must establish a relationship with the wider community. The implementation of these responsibilities requires the school principal to have leadership skills and skills, which must be prepared since the nomination of the principal.

The teacher is a determinant of the success of education through its work at the institutional and instructional level. The strategic role is in line with Law Number 14 of 2005 concerning teachers and lecturers, which places the position of teachers as professionals as well as agents of learning.

In Law Number 14 of 2005 concerning Teachers and Lecturers, Article 1 paragraph 1 emphasizes that teachers are professional educators with the main task of educating, teaching, guiding, directing, training, evaluating, and evaluating students in early childhood education through formal education, basic education, and secondary education.

The level of success of teachers in completing work is called the term "level performance" or level of work. Teachers who have a high level of work are teachers whose productivity is high and vice versa. Karwati and Priansa (2013: 40), stated: "the teaching work of teachers involves several things such as quality, skill level, cultural and educational background, attitudes, interests and motivation, discipline, work ethic, work structure, expertise, and age of the generation work."

One of the criteria for teaching teachers is discipline. Discipline can be interpreted as an act that is right and regulated. The purpose of discipline itself is to form good behavior and can become a habit. The need for discipline so that every human being can develop his attitude of obedience, awareness of his obligations, and develop morale.

The headmaster of kindergarten is the functional staff of teachers who are given the task of leading formal education institutions where the teaching and learning process is held or the place of interaction between teachers which provides lessons with students who receive lessons. The word lead from the formula implies broad meaning, namely the ability to move all resources that exist in a formal educational institution so that it can be utilized maximally to achieve the stated goals. In the practice of educational institutions, the word lead contains connotations of moving, directing and others.

Mulyasa (in Karwati and Priansa, 2013: 38) suggests "the success of education in schools is largely determined by the success of the Principal in managing the education staff available at school." The headmaster of kindergarten is one of the components of education that influences the work of teachers. The headmaster of Kindergarten is responsible for organizing educational activities, school administration, coaching other educators, and utilizing and maintaining facilities and infrastructure.

It is important in line with the increasingly complex demands of tasks for formal education institutions, which require more effective and efficient work support. In addition, the development of science and technology, as well as the arts and culture that are applied in education in schools also tend to move more forward, thus demanding professional mastery.

Each Headmaster of Kindergarten is faced with the challenge of carrying out education development in a directed, planned and sustainable manner. The headmaster of kindergarten as the highest leader who is very influential and determines the progress of formal education institutions must have administrative skills, have a high commitment and be flexible in carrying out their duties. The leadership of a good kindergarten leader must be able to carry out their duties and be able to strive to increase work through educational staff capacity building programs. 
Therefore, the headmaster of kindergarten must have a personality or traits and abilities and skills to lead an educational institution.

There are three things that underlie the birth of leadership theory according to Suhardan et al. (2012: 123) "genetic theory, social theory, and ecological theory." The theory is (1) genetic theory is a theory that explains that people become leaders, because from birth he has the talent as a leader and is indeed destined as a leader; (2) Social theory, which is a theory that says that a leader must be formed, does not just appear and be destined as a leader, therefore a leader becomes a leader because of the process of education and training; (3) Ecological theory, which is a theory which is a combination of the two theories above, in which it is explained that a person becomes a leader because his talent from birth is then developed with education and training which is also influenced by the surrounding environment.

According to Robbins (2007: 172), in leadership, there are several behaviors that we know, but in general are divided into three namely democratic, involving subordinates, delegating authority, and encouraging participation. This leadership style assumes that people's opinions are much better than their own opinions, besides that it will have an impact on their implementation responsibilities. Autocratic, dictate work methods, centralize decision making, and limit participation. This style is usually used by leaders who have high status, a person who has power and has the ability to make decisions. Laissez-faire (free), gives the group the freedom to make decisions in completing work. In this style the leader will leave the decision making to the interests of the group, what is best according to the group is the decision of the leader.

In leading a formal education institution, leadership style is a characteristic of a leader. A formal education institution achieving success one of the factors is the leadership style of the Headmaster of TK. From the description, the attitude of the teacher who wants to be improved in the leadership style is work discipline.

It can be seen from the fact that in the Southeast Pontianak Sub-district Park there are teachers who rarely enter, in one week there are always absences. Then they rarely attend school activities such as ceremonies, so they are less socialized with other teachers, and teachers do not care about the direction from the Headmaster of TK.

Based on the reality above, the researchers are interested in conducting a study entitled "The Influence of Democratic, Autocratic and Laissez-Faire (Free) Style of Kindergarten Headmasters Against the Work Discipline of Kindergarten Teachers in Southeast Pontianak Sub-District."

\section{RESEARCH METHOD}

The research approach used in this study is a quantitative approach. Sugiyono (2013: 7) suggests "the method is called quantitative because research data in the form of numbers and analysis using statistics." Therefore the data in this study are in the form of numbers, then described descriptively because it will be directed to describe the data and answer the formulation of the problem.

Arikunto (2010: 173), argues "population is the whole object of research." From this understanding, it can be concluded that the population is the whole object of the study presented data sources in discussing research, while the source of data in research is someone who has certain characteristics of an object.

The data source referred to in this study is the Headmaster of Kindergarten and Kindergarten teachers in the Southeast Pontianak Subdistrict of Pontianak City which amounts to a total of 83 people from 7 public and private kindergartens.

Arikunto (2010: 174), states "the sample is part or representative of the population under study." If the population is large, and researchers are unlikely to learn everything in the population, for example, because of limited funds, energy and time, researchers can use samples taken from the population. In this study using a non-random sample that is using purposive sampling, Subana (2011: 126) purposive sampling emphasizes the consideration of certain characteristics of the research subject. From the data above there are 34 teachers with characteristics of restrictions.

The characteristics of these restrictions are:

a. Public and Private Kindergartens in Southeast Pontianak District

b. Teachers who have graduated (S1)

c. Working period as a teacher for at least two years

\section{A. Result}

\section{RESULT AND DISCUSSION}

This research was conducted on educators, especially in kindergartens in Southeast Pontianak sub-district. Educators who are used as objects in this study are educators in Kindergarten in Southeast Pontianak Subdistrict, educators who have a Bachelor (S1), and a minimum of 2 years of work.

1. Validity Test

After the scoring process in the questionnaire, the validity of the corrected questionnaire was tested, using SPSS 22 software. Validity test was conducted to find out whether the measurement tools that have been prepared can be used to measure accurately using the Bivariate Pearson (Pearson Product Moment Correlation) method.

From the results of the analysis can be assessed the correlation between the score of the item with the total score. This value is then compared with 
the r-value of the table, $r$ table is sought at the significance level of 0.05 with a two-sided test and the amount of data $(n)=n-1=33-1=32$ than in the table $\mathrm{r}$ can be 0.349 .

If the correlation coefficient $r_{i}(r$ count $) \geq$ 0.349 then the statement item is valid. However, if the correlation coefficient $r_{i}$ ( $r$ count $) \leq 0.349$ then the statement item is invalid. Furthermore, the statement item must be repaired or discarded.

After testing the validity of the item then the data is processed with the help of SPSS computer program. Then the results of valid and invalid statement items are known. By comparing $r$ count each item with $\mathrm{r}$ table. The number of valid statement items is 43 items. While invalid statement items are seven items. Invalid item statement is discarded or not used, so the number of items used is 43 statement items.

2. Reliability Test

According to Sarwono (2014: 84-85), "reliability is generally said to have consistency in the measurement results of the same thing if done in a different context."

The measuring instrument used to measure the level of reliability of the instrument is Cronbach Alpha to show the stability and consistency of measuring instruments. The amount of valid data that will be processed amounts to $\mathrm{N}=33$ data with a percentage $(\%)=100 \%$ and no data is issued. It means that all data is valid and then tested for reliability.

From the results of the above analysis can be obtained the Alpha value of 0.901 for the leadership style of the Kindergarten Headmaster and 0.873 for the discipline of the performance of Kindergarten teachers, while the value of $r$ Table (test 2 sides) at a significant 0.05 with the number of data $n-1=33-1=$ 32 is obtained at 0.349 . Because Cronbach Alpha values are more than 0.349 , it can be concluded that the instrument items are reliable.

\section{A. Descriptive Analysis}

At the end of a study, it is necessary to conclude an answer to the existing problems. To formulate these conclusions, the data collected must be analyzed first.

1. Presentation of Data

a. Questionnaire results

In this study, the sample was kindergarten teachers in Southeast Pontianak Subdistrict. Based on the questionnaire distributed to respondents, the respondent's answer data was obtained from kindergarten teachers in Southeast Pontianak Sub-district. The following is the data of the independent variable (X) and the dependent variable (Y) in tables 4.5 and 4.6, while the results data can be seen in the appendix.

1) Leadership Style of the TK Headmaster
Table I

Free variable data $(\mathrm{X})$

\begin{tabular}{|c|c|c|c|c|c|}
\hline $\begin{array}{c}\text { Type of Leadership } \\
\text { Style }\end{array}$ & $\begin{array}{c}\text { Questionnaire } \\
\text { items }\end{array}$ & $\begin{array}{c}\text { Number of } \\
\text { Respondents }\end{array}$ & $\begin{array}{l}\text { Type of } \\
\text { Question }\end{array}$ & $\begin{array}{l}\text { Total } \\
\text { Score } \\
\end{array}$ & Total \\
\hline \multirow[t]{10}{*}{ Democratic } & 1 & 33 & + & 121 & 1187 \\
\hline & 2 & 33 & + & 107 & \\
\hline & 3 & 33 & + & 126 & \\
\hline & 4 & 33 & + & 114 & \\
\hline & 5 & 33 & + & 124 & \\
\hline & 6 & 33 & + & 119 & \\
\hline & 7 & 33 & + & 109 & \\
\hline & 8 & 33 & + & 127 & \\
\hline & 9 & 33 & + & 123 & \\
\hline & 10 & 33 & + & 117 & \\
\hline \multirow[t]{6}{*}{ Autocratic } & 11 & 33 & - & 122 & 794 \\
\hline & 12 & 33 & - & 89 & \\
\hline & 13 & 33 & - & 109 & \\
\hline & 15 & 33 & - & 129 & \\
\hline & 16 & 33 & - & 117 & \\
\hline & 17 & 33 & - & 117 & \\
\hline \multirow[t]{9}{*}{ Laizes-faire } & 18 & 33 & + & 105 & 1.004 \\
\hline & 19 & 33 & + & 115 & \\
\hline & 20 & 33 & + & 104 & \\
\hline & 21 & 33 & + & 114 & \\
\hline & 22 & 33 & + & 85 & \\
\hline & 23 & 33 & + & 108 & \\
\hline & 24 & 33 & + & 120 & \\
\hline & 25 & 33 & - & 131 & \\
\hline & 26 & 33 & + & 122 & \\
\hline
\end{tabular}

2) Performance Discipline of Kindergarten Teachers Table II

Bonded Variable Data (Y)

Performance Discipline of Kindergarten Teachers

\begin{tabular}{ccc}
\hline $\begin{array}{c}\text { Questionnaire } \\
\text { Items }\end{array}$ & Number of Respondents & Total Score \\
\hline 27 & 33 & 131 \\
\hline 28 & 33 & 137 \\
\hline 29 & 33 & 141 \\
\hline 30 & 33 & 138 \\
\hline 31 & 33 & 144 \\
\hline 32 & 33 & 152 \\
\hline 33 & 33 & 139 \\
\hline 34 & 33 & 138 \\
\hline 35 & 33 & 139 \\
\hline 36 & 33 & 144 \\
\hline 37 & 33 & 129 \\
\hline 38 & 33 & 140 \\
\hline 39 & 33 & 140 \\
\hline 40 & 33 & 142 \\
\hline 41 & 33 & 149 \\
\hline 42 & 33 & 150 \\
\hline 43 & 33 & 2401 \\
\hline & &
\end{tabular}

2. Data processing

The data presented in this study is the results of questionnaire data in the form of answers from respondents, namely teachers or kindergarten educators in the District of Southeast Pontianak. After all, questionnaires have been collected, then first checked to find out whether there is a mistake in filling. To facilitate the processing and analysis of data, the results of the questionnaire data are recapitulated. The next step is to process the data while analyzing it. Based on data analysis that has been determined by the researcher to answer subproblems 1 and 2, the percentage formula is used while to answer subproblem 3 uses simple linear regression analysis with the help of SPSS.

a. Leadership Style of Kindergarten Headmasters

To find out the leadership style of the Headmaster of Kindergarten in Southeast Pontianak 
Subdistrict in the following table, the results of the calculation are presented through the percentage formula specified in the previous chapter. The formula used in calculating the percentage of the leadership style of the Headmaster of Kindergarten is as follows:

$$
\mathrm{X} \%=\mathrm{n} / \mathrm{N} \times 100 \%
$$

The following will be presented the results of data processing and data analysis based on the problem formulation

1) Democratic Leadership Style

Democratic leadership style is found in statement items 1-10. Based on the results of the data obtained, it shows that out of 33 respondents, a total score of 1,187 or $39.8 \%$ answered democratic leadership style.

2) Autocratic Leadership Style

The muscle leadership style is found in statement items 11-17. Based on the results obtained shows that out of 33 respondents, the total score of 794 or $26.5 \%$ answered the autocratic leadership style.

3) Laizes-faire Leadership Style

The laizes-faire leadership style is found in statement item 18-26

Based on the results of the study showed that out of 33 respondents, the total score was 1,004 or $33.7 \%$ answered the laizes-faire leadership style.

Based on the results of questionnaires obtained by researchers, it can be concluded that the Headmasters of Kindergarten in Southeast Pontianak Subdistrict use all existing leadership styles. However, of the three leadership styles, the leadership style that is more dominant is applied by the Headmaster of TK, namely the democratic leadership style and laizesfaire. It can be seen from the results of the percentage of democratic leadership style of $39.8 \%$, laizes-faire leadership style of 33.7 and autocratic leadership style of $26.5 \%$. It means that when viewed from the percentage range, democratic leadership style, and laizes-faire leadership style are in the range of $33.34 \%$ $-66.66 \%$ with the moderate/sufficient category. While the autocratic leadership style is in the range of $0.00 \%$ $-33.33 \%$ with a low / less category.

Then from the questionnaire that researchers have obtained, it can also be seen from the leadership style of the Headmaster of Kindergarten in Southeast Pontianak Sub-district. The leadership style of the Headmaster of Kindergarten in the Southeast Pontianak District can be seen in Table III.

Table III

Leadership Style of Kindergarten Headmaster in the District of Southeast Pontianak

\begin{tabular}{lll}
\hline No. & Initials of Formal Education Institutions & \multicolumn{1}{c}{ Leadership Style } \\
\hline 1. & TK I & Democratic \\
\hline 2. & TK UMP & Democratic \\
\hline 3. & TK A-M & Democratic \\
\hline 4. & TK PU & Autocratic \\
\hline 5. & TK I-AA & Laizes-faire \\
\hline
\end{tabular}

b. Work Discipline of Kindergarten Teachers

To find out the discipline of performance of Kindergarten teachers in Southeast Pontianak
Subdistrict in table 4.9, the following results of the calculation data are presented through the percentage formula specified in the previous chapter. The formula used in calculating the percentage of discipline of performance of kindergarten teachers is as follows:

$$
\mathrm{X} \%=\mathrm{n} / \mathrm{N} \times 100 \%
$$

A statement is contained in points 27-43. The following are presented the results of data processing and data analysis based on the formulation of the problem.

Based on the results of questionnaires that have been obtained by researchers, it was concluded that the discipline of the performance of kindergarten teachers in the Southeast Pontianak sub-district was very good. It can be seen from the results of the percentage of discipline in the performance of Kindergarten teachers of $85.01 \%$, in the range of $66.67 \%-100 \%$ in the high/good category.

c. Simple Linear Regression Analysis

Based on the results of a predetermined analysis to determine the influence of the TK Chief leadership style on the performance discipline of Kindergarten teachers in Southeast Pontianak Subdistrict, a simple linear regression formula is used through SPSS version 22. This analysis aims to predict the value of the dependent variable if the independent variables increase or decrease and to determine the direction of the relationship between the independent variables and the dependent variable whether positive or negative. The simple linear equation as follows:

Information:

$$
\mathrm{Y}=\mathrm{a}+\mathrm{bx}
$$

$\mathrm{Y}=$ Performance Discipline of Kindergarten Teachers

$\mathrm{b}=$ Regression Coefficient

$\mathrm{x}=$ Leadership Style Headmaster of TK

The regression equation is as follows:

$$
\mathrm{Y}=47,338+0,280 \mathrm{x}
$$

The meaning of this equation is as follows:

1) Constants of 47,338 means that if the leadership style of the Headmaster of TK (X) is 0 , then the discipline of Kindergarten teacher performance is 47,338.

2) The leadership style variable regression coefficient of the headmaster of TK (X) is 0.280 , meaning that if the leadership style of the headmaster of TK increases 1 , then the discipline of the performance of kindergarten teachers has increased by $0.280 \mathrm{x}$. The coefficient is positive means that there is a positive relationship between the leadership style of the Kindergarten Headmaster and the discipline of the performance of Kindergarten teachers, the higher the leadership style of the Headmaster of Kindergarten, the more disciplined the performance of Kindergarten teachers.

d. Multiple Linear Regression Analysis

After knowing the effect of the leadership style of the TK headmaster on the discipline of performance of kindergarten teachers in the Southeast 
Pontianak sub-district, then the leadership styles were analyzed one by one. Based on the results of a predetermined analysis to determine the effect of the TK Chief leadership style on the performance discipline of Kindergarten teachers in Southeast Pontianak Subdistrict, the multiple linear regression formula through SPSS version 22 was used. Crammer and Howwit (in Sarwono 2014: 139) regression equations express linear relations between dependent variables/criterion variables given symbol $\mathrm{Y}$ and one or more independent variables/predictors given the symbol $\mathrm{X}$ if only one predictor and $\mathrm{X} 1 \mathrm{X} 2$ to $\mathrm{Xk}$, if more than one predictor. The equation is as follows:

$$
\mathrm{Y}^{\prime}=\mathrm{a}+\mathrm{b} 1 \mathrm{X} 1+\mathrm{b} 2 \mathrm{X} 2+\mathrm{b} 3 \mathrm{X} 3 \ldots+\mathrm{bnXn}
$$

Information:

Y $=$ Discipline of Kindergarten teacher performance

X1X2X3 = Kindergarten leadership style (democratic, autocratic, and laizes-faire)

a $\quad=$ Constants

$\mathrm{b}=$ regression coefficient.

In this section is a correlation matrix between:

1) The leadership style of the Headmaster of Kindergarten is democratic towards the discipline of performance of Kindergarten teachers in Southeast Pontianak Subdistrict with $r=0.714, r$ is positive, there is a positive relationship between the leadership style of the Headmaster of Kindergarten who is democratic towards the discipline of performance of Kindergarten teachers in Southeast Pontianak Subdistrict.

2) The autocratic leadership style of the Kindergarten Headmasters towards the performance discipline of Kindergarten teachers in Southeast Pontianak Subdistrict with $r=0.685$, is positive, so there is a positive influence between the autocratic leadership style of the Kindergarten Headmasters on the discipline of Kindergarten teachers performance in Southeast Pontianak District.

3) The kindergarten leader's leadership style is laizes-faire towards the performance discipline of kindergarten teachers in Southeast Pontianak Subdistrict with $r=0.713, r$ is positive then there is a positive influence between leadership style of the Headmaster of Kindergarten who is laizesfaire towards the discipline of Kindergarten teacher performance in the District of Southeast Pontianak.

e. Partial Test (t-test)

This test is used to determine whether the independent variable partially has a significant effect on the dependent variable, so the t-test is conducted to determine whether the leadership style of the Headmaster of Kindergarten (X) has a significant effect on the performance discipline of Kindergarten (Y) teachers.

To determine the relationship significantly, the $t$ count value must be compared with $t$ table. The value of $t$ table can be found by determining the degree of freedom (df) nk-1 that is (33-2-1) on the one-sided test of 0.05 so that the $t$-table value is 1.697 , with the test criteria that is if $\mathrm{t}$ counts $\geq \mathrm{t}$ table then $\mathrm{Ha}$ accepted, and Ho refused. Conversely, if $\mathrm{t}$ counts $\leq \mathrm{t}$ table, then Ha is rejected, and Ho is accepted.

1) Ha: There is significant influence between the leadership style of the Kindergarten Headmaster and the discipline of the performance of Kindergarten teachers in Southeast Pontianak District.

2) Ho: There is no significant influence between the leadership style of the TK headmaster on the discipline of performance of kindergarten teachers in the Southeast Pontianak sub-district.

Then to find out the significant relationship between independent variables, namely the leadership style of the headmaster of a TK that is democratic, the leadership style of the headmaster of an autocratic kindergarten, and the leadership style of the headmaster of kindergarten which is laizes-faire (X1, $\mathrm{X} 2, \mathrm{X} 3$ ) significantly influence the discipline of performance of the kindergarten teacher children in the District of Southeast Pontianak (Y) carried out a ttest.

To determine the effect significantly, the calculated $t$ value must be compared with $t$ table. The $t$ table value can be found by determining the degree of freedom (df) n-k-1 that is (33-2-1) on the one-sided test of 0.05 so that the t-table value is 1.697 . In the table above the leadership style of the Headmaster of Democratic TK is a leadership style that has a positive and significant influence can be seen $\mathrm{t}$ count $\geq \mathrm{t}$ table $(5,675 \geq 1,697)$. While the autocratic leadership style and laizes-faire style in the table above are included in Excluded variables, which means that the variable is excluded.

\section{B. Discussion}

Based on the number of respondents in this study, the questionnaires distributed were 33 questionnaires with a total of 43 items and based on the validity test and reliability test all valid and reliable items so that all 43 items were used. Data obtained through questionnaires are qualitative. Therefore, the data must still be quantified by giving a score for each answer option.

In addition, from the results of research and data analysis through questionnaires to determine the leadership style of the Headmaster of Kindergarten in Southeast Pontianak District using the percentage formula (\%), the percentage of democratic leadership styles was $39.8 \%$, autocratic leadership style was $26.5 \%$, and laizes-faire leadership style is $33.7 \%$. So it can be concluded that the Headmaster of Kindergarten in Southeast Pontianak Subdistrict uses all existing leadership styles. However, of the three leadership styles, the leadership style that is more dominant is applied by the Headmaster of Kindergarten, namely 
democratic leadership style and laizes-faire leadership style. Because when viewed from the percentage range, democratic leadership style, and laizes-faire leadership style are in the range of $33.34 \%-66.66 \%$ with the moderate/sufficient category.

It means that the democratic leadership style is a leadership style commonly used by the Headmaster of Kindergarten in Southeast Pontianak Sub-district. It conducted by researchers from 5 schools in Southeast Pontianak Subdistrict, there are three kindergartens that are democratic, and $1 \mathrm{TK}$ leadership style is autocratic, and one kind of leadership style. faire.

As well as the correlation calculation, there is a leadership style of the headmaster of a kindergarten that is democratic towards the performance discipline of kindergarten teachers in the Southeast Pontianak sub-district with $r=0.714$, positive value, there is a positive relationship between the leadership style of the headmaster of kindergarten who is democratic towards the performance of kindergarten teachers. In the District of Southeast Pontianak. The autocratic leadership style of the Kindergarten Headmasters towards the performance discipline of Kindergarten teachers in Southeast Pontianak Subdistrict with $\mathrm{r}=$ 0.685 , is positive, so there is a positive influence between the autocratic leadership style of the Kindergarten Headmasters on the discipline of Kindergarten teachers performance in Southeast Pontianak District. And the kindergarten leader's leadership style is laizes-faire towards the performance discipline of kindergarten teachers in Southeast Pontianak Subdistrict with $r=0.713, r$ is positive then there is a positive influence between leadership style of the Headmaster of Kindergarten who is laizes-faire towards the discipline of Kindergarten teacher performance in the District of Southeast Pontianak.

It means that all leadership styles of the Headmaster of Kindergarten in Southeast Pontianak Subdistrict have a positive effect on the discipline of the performance of Kindergarten teachers. However, in $\mathrm{r}$ arithmetic, we can see that the leadership style of the headmaster of a democratic kindergarten has the largest count among other leadership styles so that the leadership style of the headmaster of a democratic kindergarten is the most positive influence on the performance discipline of kindergarten teachers in Southeast Pontianak sub-district. Then after that, the leadership style of the Headmaster of Kindergarten is laizes-faire, and the leadership style of the Headmaster of the TK is autocratic. It can be seen in the figure below:

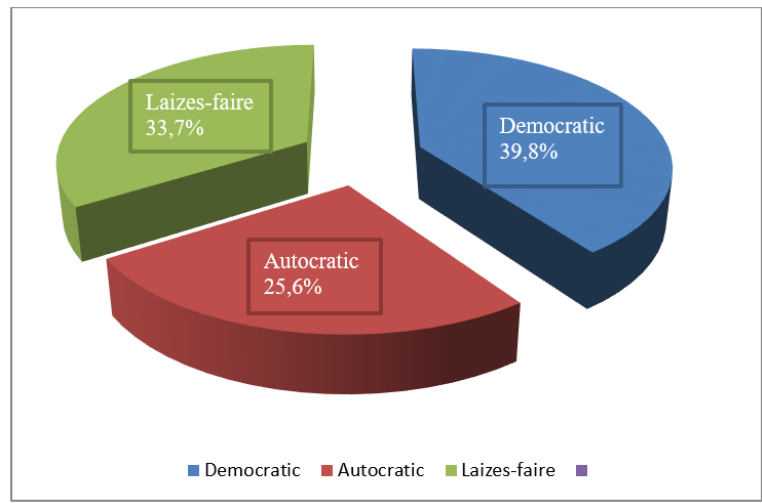

Fig. 1 Percentage of Leadership Style of Kindergarten Principal in the District of Southeast Pontianak

It is in accordance with the opinion of Karwati and Priansa (2013: 178) "In general, the three leadership styles of principals most widely known are autocratic, democratic and laiszez faire leadership styles."

Suhardan, et al. (2012: 127) educational leadership can be classified into three types, namely:

1. Autocratic type

This type of autocratic leadership is also called the "authoritarian" type of leadership. In autocratic leadership, leaders act as dictators of group members. Excessive domination easily revives the opposition or gives rise to apathy towards group members towards their leaders.

2. Laiszez-faire type

In this type of leadership actually, the leader does not give his leadership, he allows his subordinates to do what they want. The leader does not give control and correction to the work of his subordinates.

3. Democratic type

The democratic type leader interprets his leadership not as a dictator, but as a leader in the midst of his group members. Democratic leaders always try to stimulate members to work productively to achieve common goals.

Among the three leadership styles, a good leadership style used to improve the performance discipline of kindergarten teachers is a democratic leadership style. Where this leadership style presents an equal space in the opinion, so that the teacher, staff, and other employees have equal rights to contribute to the responsibilities they carry out. This leadership style views teachers, staff, and other employees as part of the whole formal institution so that it gets a place in accordance with its dignity as a human. The Headmaster of Kindergarten has the responsibility and duty to direct, control, and evaluate, as well as coordinate the various tasks carried out by teachers, staff, and other employees. But all leadership styles can be applied as needed. 
Furthermore, to discipline the performance of teachers, it can be concluded that the discipline of the performance of Kindergarten teachers in Southeast Pontianak Subdistrict is already good. It can be seen from the results of the discipline percentage of teacher performance of $85.01 \%$, in the range of $66.67 \%-100 \%$ in the high/good category.

The content in accordance with Siagian's opinion in Sutrisno (2009: 86), a good form of discipline will be reflected in the atmosphere within the school organization, namely:

1. The teacher's high sense of care towards the achievement of the school's vision and mission.

2. The high level of enthusiasm, passion for work and the initiative of teachers in teaching.

3. The amount of the teacher's sense of responsibility to carry out the task as well as possible.

4. Growing sense of belonging and a high sense of solidarity among teachers.

5. Improve work efficiency and productivity.

Then to find out the significant or nonsignificant influence between the leadership style of the TK headmaster on the discipline of performance of Kindergarten teachers in Southeast Pontianak Subdistrict, a significance test or t-test was carried out. Based on the results of the calculation of the t-test obtained t count value of 5.562 with $\mathrm{N}=33$ obtained $\mathrm{t}$ table of 2.042, thus $t$ count $>t$ table (5.562> 2.042). Thus, Ha accepted Ho refused so that it can be concluded that there is significant influence between the leadership style of the Kindergarten Principals on the performance discipline of Kindergarten teachers in Southeast Pontianak Subdistrict.

Whereas to find out significant or nonsignificant effects between:

1. The leadership style of the Headmaster of Kindergarten is democratic towards the discipline of performance of Kindergarten teachers in Southeast Pontianak Subdistrict, so a significance test or t-test is carried out. Based on the results of the t-test calculation obtained $\mathrm{t}$ count of 5.675 with $\mathrm{N}=33$ obtained $\mathrm{t}$ table 1.697 , then $\mathrm{t}$ count> $t$ table (5.675> 1.697). Thus, there is significant influence between the leadership style of the Headmaster of Kindergarten who is democratic towards the discipline of performance of Kindergarten teachers in Southeast Pontianak District.

2. The autocratic leadership style of the headmaster of kindergarten towards the discipline of the performance of kindergarten teachers in the Southeast Pontianak sub-district, a significance test or t-test is carried out. Based on the results of the t-test calculation obtained $\mathrm{t}$ count of 1.071 with $\mathrm{N}=33$ obtained $\mathrm{t}$ table 1.697 , then $\mathrm{t}$ count $<\mathrm{t}$ table $(1.071$ <1.697). Thus there is a nonsignificant influence between the autocratic leadership style of the Headmaster of
Kindergarten on the discipline of the performance of Kindergarten teachers in Southeast Pontianak Subdistrict.

3. The leadership style of the TK headmaster is laizes-faire towards the discipline of the performance of Kindergarten teachers in the Southeast Pontianak Subdistrict, so a significance test or t-test is carried out. Based on the results of the t-test calculation obtained t count of 0.967 with $\mathrm{N}=33$ obtained $\mathrm{t}$ table 1.697 , then $\mathrm{t}$ count $<\mathrm{t}$ table (0.967> 1.697). Thus there is a nonsignificant influence between the autocratic leadership style of the Headmaster of Kindergarten on the discipline of the performance of Kindergarten teachers in Southeast Pontianak Subdistrict.

From the explanation above, it can be concluded that the leadership style of the headmaster of a kindergarten who is democratic has a significant influence or has a strong influence in improving the discipline of performance of kindergarten teachers in Southeast Pontianak sub-district. Whereas the leadership style of Autocratic and laizes-faire Kindergarten Headmasters has a non-significant effect which means that the leadership style is influential, but not strong in improving the discipline of performance of Kindergarten teachers in Southeast Pontianak District. It is in accordance with the opinion of Harsoni (in Setyaningrum 2010: 13 (online)) stating "work discipline is the result of interaction between external and internal factors of individuals, these factors include factors of leadership, moral factors, and job satisfaction factors."

It means that one that influences the discipline of teacher performance, namely the factor of the leadership of the binder and controlling the unity of life is a hierarchical discipline and system. Therefore the strength of the leader expressed in authority creates a harmonious and directed system of unity without causing adverse effects on its unity.

\section{CONCLUSIONS AND SUGGESTIONS}

\section{A. Conclusions}

From the results of research and data analysis that has been carried out, it can be concluded that there is significant influence between the leadership style of the Kindergarten Principals on the performance discipline of Kindergarten teachers in Southeast Pontianak District. The specific conclusions that can be drawn by the researcher are as follows:

1. Leadership Style of Kindergarten Headmasters in Southeast Pontianak District

a. The leadership style of the Kindergarten Headmasters in Southeast Pontianak Subdistrict varied. The leadership style of the Headmaster of Kindergarten in Southeast Pontianak Subdistrict was applied not only to one leadership style but to using all existing 
leadership styles. However, the leadership style that is more dominant is applied by the Headmaster of Kindergarten, namely the democratic leadership style and laizes-faire leadership style. It can be seen from the results of the percentage of democratic leadership style of $39.8 \%$, autocratic leadership style of $26.5 \%$, and laizes-faire leadership style of $33.7 \%$. When viewed from the range of percentage of democratic leadership style and laizes-faire leadership style, it is in the range of $33.34 \%-66.66 \%$ with the moderate/sufficient category. It means that the leadership style of the Kindergarten Headmaster influences the discipline of Kindergarten teacher performance.

b. The democratic leadership style that is most commonly used by the Headmasters of Kindergartens in the Southeast Pontianak Subdistrict with the number $3 \mathrm{TK}$, while those using autocratic leadership styles are 1 TK. And those who use the laizes-faire leadership style amount to 1 kindergarten.

2. The discipline of the performance of kindergarten teachers in the Southeast Pontianak sub-district has been good. It can be seen from the results of the discipline percentage of teacher performance of $85.01 \%$, in the range of $66.67 \%-100 \%$ in the high/good category.

3. The influence of the TK Headmaster leadership style on the performance discipline of Kindergarten teachers in Southeast Pontianak Subdistrict

a. Based on the results of the calculation of the t-test obtained t count value of 5.562 with $\mathrm{N}$ $=33$ obtained $t$ table of 2.042 , then $t$ count $\geq$ t table (5.562 $\geq 2.042)$. Thus, Ha accepted Ho rejected so that it can be concluded that there is significant influence between the leadership style of the Kindergarten Principal on the performance discipline of Kindergarten teachers in Southeast Pontianak Subdistrict.

b. Based on the results of the t-test calculation obtained $\mathrm{t}$ count of 5.675 with $\mathrm{N}=33$ obtained t table 1.697, then $\mathrm{t}$ count $>\mathrm{t}$ table (5.675> 1.697). Thus, there is significant influence between the leadership style of the Headmaster of Kindergarten who is democratic towards the discipline of performance of Kindergarten teachers in Southeast Pontianak District.

c. Based on the results of the t-test calculation obtained $\mathrm{t}$ count of 1.071 with $\mathrm{N}=33$ obtained t table 1.697 , then $t$ count $<\mathrm{t}$ table $(1.071<1.697)$. Thus there is a nonsignificant influence between the autocratic leadership style of the Headmaster of Kindergarten on the discipline of the performance of Kindergarten teachers in Southeast Pontianak Subdistrict.

d. Based on the results of the t-test calculation obtained $t$ count of 0.967 with $\mathrm{N}=33$ obtained $\mathrm{t}$ table 1.697 , then $\mathrm{t}$ count $<\mathrm{t}$ table $(0.967>1.697)$. Thus there is a nonsignificant influence between the autocratic leadership style of the Headmaster of Kindergarten on the discipline of the performance of Kindergarten teachers in Southeast Pontianak Subdistrict.

It can be concluded that the leadership style of the headmaster of a democratic kindergarten has a strong influence on the performance discipline of kindergarten teachers in the Southeast Pontianak subdistrict, while the leadership style of the autocratic and laizes-faire headmaster of kindergarten influences but is not strong enough to discipline the performance of kindergarten teachers in Southeast Pontianak District. B. Suggestions

From the results of research conducted, the researchers suggest:

1. Each Headmaster of Kindergarten can maintain an existing leadership style so that the discipline of Kindergarten teacher performance will improve.

2. Each headmaster of kindergarten can pay attention to the use of leadership style in accordance with the situation and conditions of work at the time.

3. The leadership style of the existing TK leaders can improve the discipline of the performance of kindergarten teachers.

\section{REFERENCES}

Arikunto, S. 2010. Prosedur Penelitian. Jakarta: Rineka Cipta.

Departemen Pendidikan Nasional. 2005. UndangUndang Nomor 14 Tahun 2005, Tentang Guru dan Dosen. Jakarta: Depdiknas.

Karwati, Euis dan Priansa, Donni Juni. 2013. Kerja dan Profesionalisme Kepala Sekolah. Bandung: Alfabeta.

Robbins, S. P. 2007. Management Ninth Edition. New Jersey: Pearson Education.

Setianingrum, Heni Hapsari. 2010. Disiplin Kerja Pegawai Negeri Sipil di Tinjau dari Persepsi Terhadap Iklim Organisasi dan Kepuasan Kerja (online).

Subana dan Sudrajat. 2011. Dasar-Dasar Penelitian Ilmiah. Bandung: CV Pustaka Setia.

Suhardan, D. 2012. Manajemen Pendidikan. Bandung: Alfabeta.

Sutrisno, E. 2009. Manajemen Sumber Daya Manusia. Jakarta: Kencana. 